\title{
Microstructure and mechanical properties of Al-10Si alloy modified with $\mathrm{Al}-5 \mathrm{Ti}$
}

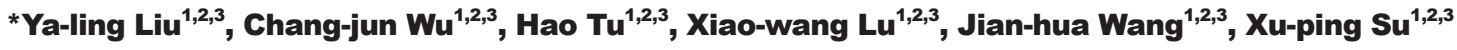 \\ 1. Jiangsu Key Laboratory of Material Surface Science and Technology, School of Materials Science and Engineering, Changzhou \\ University, Changzhou 213164, China \\ 2. National Experimental Teaching Demonstration Center of Materials Science and Engineering, Changzhou University, Changzhou \\ 213164, China \\ 3. Jiangsu Collaborative Innovation Center of Photovoltaic Science and Engineering, Changzhou University, Changzhou 213164, China
}

\begin{abstract}
The microstructure, fracture morphology and mechanical properties of $\mathrm{Al}-10 \mathrm{Si}$ alloy modified with Al-5Ti were analyzed and tested by optical microscopy, scanning electron microscopy, and universal electronic testing machine. Compared with unmodified Al-10Si alloy, the area fraction of $\alpha$-Al phase in Al-10Si alloy modified at $740{ }^{\circ} \mathrm{C}$ increased first and then decreased with the increase of added amounts of Al-5Ti, and reached the maximum when the added amount of $\mathrm{Al}-5 \mathrm{Ti}$ was $0.5 \mathrm{wt} . \%$. When the modification temperature increased from 700 to $740{ }^{\circ} \mathrm{C}$ with $\mathrm{Al}-5 \mathrm{Ti}$ being fixed at $0.5 \mathrm{wt} . \%$, a-Al dendrites were refined obviously and the area fraction remarkably increased. Compared with unmodified Al-10Si alloy, the ultimate tensile strength and elongation of the alloy modified at $740{ }^{\circ} \mathrm{C}$ with $0.5 \mathrm{wt} . \% \mathrm{Al}-5 \mathrm{Ti}$ increased by $9 \%$ and $49 \%$, respectively. The fracture surface of modified alloy predominantly exhibited ductile fracture.
\end{abstract}

Key words: Al-10Si; modification; microstructure; mechanical properties

CLC numbers: TG146.21 Document code: A Article ID: 1672-6421(2018)06-405-06

\begin{abstract}
1-Si alloys are widely used in aerospace, automobile, ship, household appliances and other industries due to the advantages such as low density, high strength, good corrosion resistance, good casting performance and excellent conductivity and thermal conductivity ${ }^{[1-3]}$. Al-Si alloy parts prepared by casting method accounts for $85 \%-90 \%$ of the total ${ }^{[4]}$. Hypoeutectic Al-Si alloy consists of coarse $\alpha$-Al dendrites and needle-like eutectic silicon. The morphologies, size and distribution of eutectic Si together with $\alpha$-Al dendrites obviously affect the mechanical properties of hypoeutectic Al-Si alloy ${ }^{[5]}$. The coarse $\alpha-\mathrm{Al}$ dendrites decrease the strength and ductility of the alloy ${ }^{[6]}$. Needle-like eutectic Si splits $\alpha$-Al matrix, resulting in the decrease of mechanical properties ${ }^{[2,7]}$. The refinement of $\alpha-\mathrm{Al}$ dendrites and the morphology improvement of eutectic Si from needle into fibrous or short rod can improve the mechanical properties of hypoeutectic Al-Si alloy ${ }^{[8,9]}$.
\end{abstract}

\section{*Ya-ling Liu}

Female, born in 1991, Master degree candidate. Her research interest mainly focuses on high performance nonferrous alloys

E-mail: 15189761135@163.com

Received: 2018-04-28; Accepted: 2018-08-11
The primary $\alpha$-Al phase can be refined by methods such as laser melting ${ }^{[0]}$, rapid solidification ${ }^{[10]}$, electromagnetic stirring $^{[11]}$ and grain refiner addition ${ }^{[7]}$. However, laser melting and rapid solidification, as well as electromagnetic stirring, require expensive equipment. Adding a grain refiner is a cheaper and simpler method. The most commonly used refiners are $\mathrm{Al}-\mathrm{Ti}^{[12,13]}, \mathrm{Al}-\mathrm{B}, \mathrm{Al}-\mathrm{Ti}^{\left[-\mathrm{B}^{[14,15]}\right.}$ and AlTi-C master alloy ${ }^{[16,17]}$, etc. Al-Ti master alloy was first used to refine $\alpha-\mathrm{Al}$ phase in pure aluminum or wrought aluminum alloy ${ }^{[18]}$. Later it is used to refine the $\alpha-\mathrm{Al}$ phase in Al-Si alloy. The modification effect of Al-Ti on aluminum alloy is unstable and fading of modification is easy to occur ${ }^{[19]}$. The modification effect of AlTi-B on $\alpha-\mathrm{Al}$ phase is better ${ }^{[20]}$, but trace elements $(\mathrm{Zr}$, $\mathrm{V}$, and $\mathrm{Cr}$ ) would react with Al-Ti-B in Al-Si alloy to produce a "poison" phenomenon ${ }^{[17,21,22]}$, resulting in the deterioration of modification effect. Al-Ti-C master alloy overcomes the shortage of Al-Ti-B master alloy ${ }^{[22]}$, but the poor wet-ability between graphite and liquid $\mathrm{Al}$ is one of the key issues in the production of Al-Ti-C grain refiner.

To date, research mainly focused on the effect of modification on $\alpha$-Al phase refining and the morphology change of eutectic Si in hypoeutectic Al-Si alloys. Little attention was paid to the influence of modification on the movement of non-equilibrium eutectic point in $\mathrm{Al}-\mathrm{Si}$ 
alloy and the resulting change of the area fraction of $\alpha$-Al phase, as well as the mechanical properties of hypoeutectic Al-Si alloys. In order to analyze the modification effect of titanium on Al-Si alloys and decrease the influence of other elements, Al-5Ti was used as a refiner. The microstructure and mechanical properties of Al-10Si alloy modified with Al-5Ti were investigated. The study is of significance to improve the mechanical properties of Al-Si alloy and to expand its application field in industry.

\section{Experimental procedure}

Al-10Si alloy was prepared using raw materials of industrial pure aluminum (99.97\%, mass fraction, hereinafter), and Al$50 \% \mathrm{Si} .2000 \mathrm{~g}$ ingots of Al-10Si alloy were prepared as follows: $400 \mathrm{~g} \mathrm{Al}-50 \% \mathrm{Si}$ master alloy was placed at the bottom of a graphite crucible, and then 1,600 g pure aluminum was put on top of the $\mathrm{Al}-50 \% \mathrm{Si}$. The alloys were melted in a resistance furnace at $740{ }^{\circ} \mathrm{C}$ for $30 \mathrm{~min}$. At last, small ingots were obtained by pouring the melt into a metal mold at room temperature.

The $200 \mathrm{~g}$ Al-10Si alloy was remelted in a graphite crucible furnace at $740{ }^{\circ} \mathrm{C}$. The melting surface was covered with complex salt (mass ratio of $\mathrm{NaCl}: \mathrm{KCl}: \mathrm{Na}_{3} \mathrm{AlF}_{6}$ is $\left.6: 9: 5\right)$ to reduce the oxidation and burning of alloy melt. Chemical analysis showed that the fluctuation of silicon content was less than $3 \%$. To investigate the effect of added amounts of Al-5Ti on modification effect of Al-10Si alloy, 0.1, 0.3, 0.5, 0.7 and $0.9 \mathrm{wt} . \%$ of Al-5Ti, respectively, was added in the melt and kept for $3 \mathrm{~min}$. $\mathrm{C}_{2} \mathrm{Cl}_{6}$ was used for degassing treatment. To investigate the effect of temperature on modification effect of Al-10Si alloy, $200 \mathrm{~g} \mathrm{Al}$ $10 \mathrm{Si}$ alloy was remelted and modified with $0.5 \mathrm{wt} . \%$ of Al-5Ti at $700{ }^{\circ} \mathrm{C}, 740{ }^{\circ} \mathrm{C}$ and $780{ }^{\circ} \mathrm{C}$ for $3 \mathrm{~min}$, respectively. Finally, the modified melt was poured into a steel mold with an inner size of

\section{$\Phi 12 \mathrm{~mm} \times 100 \mathrm{~mm}$}

Metallographic samples were cut from the casting samples at a position of $10 \mathrm{~mm}$ from the bottom. The samples were polished and further etched with Keller's reagent. The microstructure of the samples was observed and analyzed using a Leica DIM3000 optical microscope. The area fraction of $\alpha-\mathrm{Al}$ in Al-10Si alloy was measured with Photoshop software. The value was the average of three measurements. Tensile tests were carried out on specimens with $6 \mathrm{~mm}$ gauge diameter and $30 \mathrm{~mm}$ gauge length at a stretching rate of $2 \mathrm{~mm} \cdot \mathrm{s}^{-1}$ using a WDW-300 universal tensile testing machine and following ASTM E8 standard; the value was the average of three measurements. Characterization of fracture morphologies of the tensile samples of Al-10Si alloy was carried out with a JSM-6360LV scanning electron microscope.

\section{Results and discussion}

\subsection{Effect of Al-5Ti addition amount on microstructure of Al-10Si alloy}

Figure 1 shows the microstructures of Al-10Si alloy modified with different amounts of Al-5Ti at $740{ }^{\circ} \mathrm{C}$. As shown in Fig. 1 (a), coarse dendritic primary $\alpha-\mathrm{Al}$ and eutectic microstructure are apparent in the unmodified Al-10Si alloy. The distribution of dendritic primary $\alpha$-Al is uneven. The $\alpha$-Al dendrites after modification with $0.1 \mathrm{wt}$.\% Al-5Ti are obviously refined and its amounts increases. The distribution of $\alpha-\mathrm{Al}$ dendrites is more uniform. When the added amounts of Al-5Ti increases from $0.1 \mathrm{wt} . \%$ to $0.5 \mathrm{wt} . \%$, the amount of $\alpha-\mathrm{Al}$ dendrites increased gradually. After the added amounts of Al-5Ti is more than $0.5 \mathrm{wt} . \%$, the amount of $\alpha$-Al dendrites decreases and the $\alpha$-Al dendrites become coarse with the increasing of Al-5Ti.
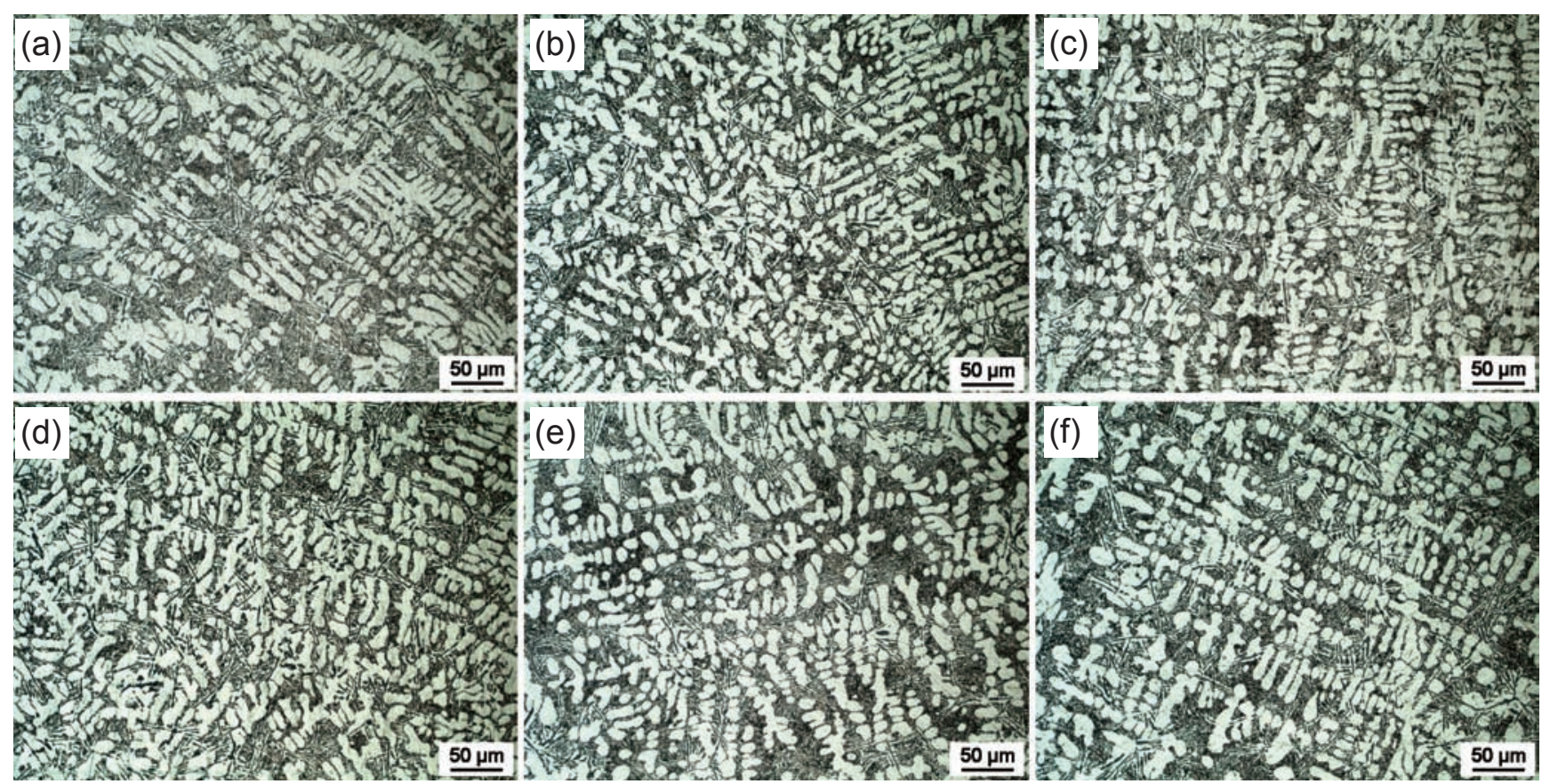

Fig. 1: Microstructures of Al-10Si modified with different amounts of Al-5Ti: (a) $0.0 w t . \%$; (b) $0.1 w t . \%$; (c) $0.3 w t . \%$; (d) $0.5 w t . \%$; (e) $0.7 w t . \%$; (f) $0.9 w t . \%$ 
Table 1 shows the quantitative analysis of area fraction of $\alpha$-Al phase in Al-10Si alloy modified with different amounts of Al-5Ti at $740{ }^{\circ} \mathrm{C}$. As shown in Table 1, the area fraction of $\alpha$-Al phase increases first and then decreases with increasing addition of Al-5Ti from 0.1 to $0.9 \mathrm{wt} . \%$. The area fraction of $\alpha-\mathrm{Al}$ phase reaches the maximum when the added amount of Al-5Ti is 0.5 wt. $\%$, which is in agreement with Fig. 1.

Table 1: Area fraction of primary $\alpha-\mathrm{Al}$ in Al-10Si modified with different amounts of Al-5Ti

\begin{tabular}{|ccccccc|}
\hline Al-5Ti (wt.\%) & 0 & 0.1 & 0.3 & 0.5 & 0.7 & 0.9 \\
\hline Area fraction of primary $\alpha-\mathrm{Al}(\%)$ & 41.4 & 47.5 & 51.0 & 52.8 & 46.3 & 45.4 \\
\hline
\end{tabular}

Eutectic Al-Si alloy modified with Al-3P or Al-5Ti could change the non-equilibrium eutectic point of Al-Si phase $\operatorname{diagram}^{[23,24]}$, so hypoeutectic Al-Si alloy modified with Al$5 \mathrm{Ti}$ could also change the non-equilibrium eutectic point of Al-

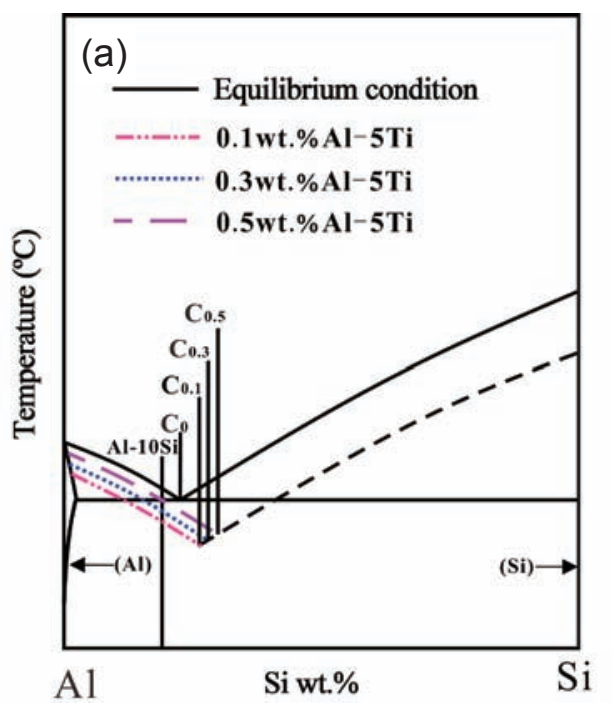

Si system. The variation of the area fraction of $\alpha-\mathrm{Al}$ phase in modified Al-10Si alloy can be explained by the movement of non-equilibrium eutectic point of Al-Si binary system, as shown in Fig. 2.

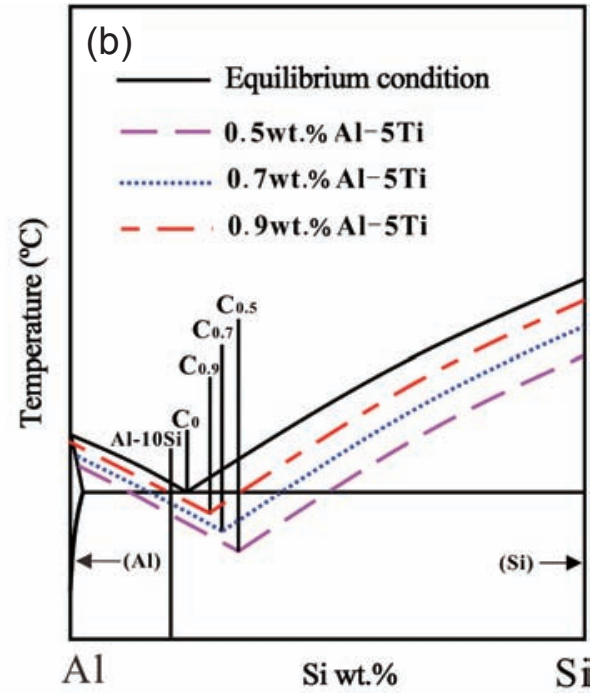

Fig. 2: Schematic of eutectic point variation of Al-Si alloy modified with different amounts of Al-5Ti: (a) less than $0.5 \mathrm{wt} . \% \mathrm{Al}-5 \mathrm{Ti}$; (b) more than $0.5 \mathrm{wt} . \% \mathrm{Al}-5 \mathrm{Ti}$

In Fig. 2, $\mathrm{C}_{0}$ is the equilibrium eutectic point in Al-Si phase diagram, $\mathrm{C}_{0.1}, \mathrm{C}_{0.3}, \mathrm{C}_{0.5}, \mathrm{C}_{0.7}$ and $\mathrm{C}_{0.9}$ represent non-equilibrium eutectic points, corresponding to the melt modified with $0.1,0.3$, 0.5, 0.7 and $0.9 w t . \% \mathrm{Al}-5 \mathrm{Ti}$, respectively at $740{ }^{\circ} \mathrm{C}$.

Modification of Al-Si alloy with Al-5Ti had little direct impact on the nucleation and growth of primary Si. When the added amounts of Al-5Ti was less than $0.5 \mathrm{wt} . \%$, the effect of modifier on the temperature of liquid Al-Si alloy was also very small. The undercooling degree of hypereutectic Al-Si alloy was almost at a certain value after modification with a small amount of Al5Ti, as shown in Fig. 2(a). $\mathrm{Al}_{3}$ Ti particles in Al-5Ti master alloy could act as the effective nucleation core of primary $\alpha$-Al phase in hypoeutectic Al-Si alloy, resulting in an obvious decrease in undercooling degree of hypoeutectic Al-Si alloy ${ }^{[24,25]}$. The nonequilibrium eutectic point of the hypoeutectic Al-Si alloy would shift to the right because of the decrease of undercooling degree. With the increase of the added amounts of Al-5Ti, the number of $\mathrm{Al}_{3} \mathrm{Ti}$ particles increased, further resulting in the decrease of undercooling degree of hypoeutectic Al-Si alloy, as shown in Fig. 2(a). According to Lever's law, the area fraction of $\alpha-\mathrm{Al}$ phase in Al-10Si alloy would increase with the added amounts of Al-5Ti.
When the added amounts of Al-5Ti was more than 0.5wt.\%, the effect of modifier on the temperature of Al-Si alloy is shown in Fig. 2(b). The more the added amounts of Al-5Ti, the more the temperature of alloy decreased, resulting in the decrease of the cooling rate of the alloy, and finally, the undercooling degree of Al-Si alloy decreased. In addition, the undercooling degree of hypoeutectic Al-Si alloy was much lower than that of hypereutectic Al-Si alloy due to the modification effect of Al-5Ti, as shown in Fig. 2(b). When the added amounts of Al-5Ti were from $0.5 \mathrm{wt} . \%$ to $0.9 \mathrm{wt} . \%$, the non-equilibrium eutectic point of Al-Si alloy would also move to the right. With the increase of the added amounts of Al-5 Ti, the moving distance of the nonequilibrium eutectic point to the right would be decreased. As a result, $\mathrm{C}_{0.7}$ is on the left side of $\mathrm{C}_{0.5}$ and $\mathrm{C}_{0.9}$ is on the left side of $\mathrm{C}_{0.7}$. According to Lever's law, when the added amounts of Al5 Ti increased from $0.5 \mathrm{wt} . \%$ to $0.9 \mathrm{wt} . \%$, the area fraction of $\alpha-\mathrm{Al}$ phase in Al-10Si alloy decreased, as shown in Table 1.

\subsection{Effect of modification temperature on microstructure of $\mathrm{Al}-10 \mathrm{Si}$ alloy}

Figure 3 shows the microstructure of Al-10Si alloy modified with $0.5 \mathrm{wt} . \% \mathrm{Al}-5 \mathrm{Ti}$ at different temperatures. When the modification 

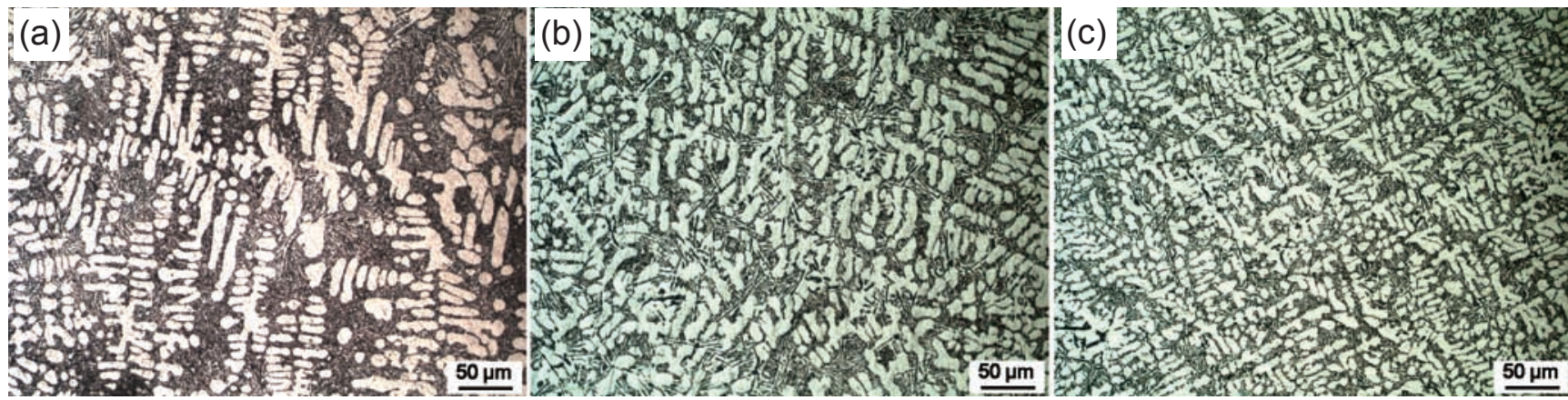

Fig. 3: Microstructures of Al-10Si alloy modified with $0.5 \mathrm{wt} . \% \mathrm{Al}-5 \mathrm{Ti}$ at different temperatures: (a) $700{ }^{\circ} \mathrm{C}$; (b) $740{ }^{\circ} \mathrm{C}$; (c) $780{ }^{\circ} \mathrm{C}$

temperature was $700{ }^{\circ} \mathrm{C}$, the size of $\alpha$-Al phase was relatively larger and its amount was less. When the temperature increased to $740{ }^{\circ} \mathrm{C}$, the $\alpha$-Al phase was obviously refined. The area fraction of $\alpha-\mathrm{Al}$ phase increased significantly and distributed more uniformly. When the temperature reached $780{ }^{\circ} \mathrm{C}$, the $\alpha$-Al phase was further refined and its number was further increased compared with that in Al-10Si alloy modified at $740{ }^{\circ} \mathrm{C}$. With the increase of temperature, the $\alpha$-Al phase became finer and finer, the area fraction of the phase became greater and greater. When the temperature increased from 700 to $740{ }^{\circ} \mathrm{C}$, the refining extent of the $\alpha$-Al phase was more obvious and the increased amount of the phase was much more than that from 740 to $780{ }^{\circ} \mathrm{C}$.

The quantitative analysis results of the area fraction of $\alpha$-Al phase in Al-10Si alloy modified with $0.5 \mathrm{wt} . \%$ Al-5Ti at different temperatures are shown in Table 2 . It was clearly seen from Table 2 that the area fraction of $\alpha$-Al phase obviously increased when the modification temperature increased from 700 to $740{ }^{\circ} \mathrm{C}$, and increased a little when the temperature further increased from 740 to $780^{\circ} \mathrm{C}$. From the point of view of the area fraction of $\alpha-\mathrm{Al}$ phase, the most suitable modification temperature was $740{ }^{\circ} \mathrm{C}$.

Table 2: Area fraction of primary $\alpha-\mathrm{Al}$ in Al-10Si alloy modified with $0.5 \% \mathrm{Al}-5 \mathrm{Ti}$ at different temperatures

$\begin{array}{cc}\begin{array}{c}\text { Modification temperature } \\ \left({ }^{\circ} \mathrm{C}\right)\end{array} & \begin{array}{c}\text { Area fraction of primary } \\ \text { a-Al (\%) }\end{array} \\ 700 & 43.3 \\ 740 & 52.8 \\ 780 & 53.7\end{array}$

The area fraction of $\alpha-\mathrm{Al}$ phase in modified Al-10Si alloy changed with the variation of modification temperature. This could be explained through Fig. 4, which is a schematic diagram of eutectic point variation of Al-Si alloy modified with $0.5 \mathrm{wt} . \% \mathrm{Al}-5 \mathrm{Ti}$ at different temperatures. $\mathrm{C}_{0}$ is the position of equilibrium eutectic point of Al-Si alloy. $\mathrm{C}_{700}, \mathrm{C}_{740}$ and $\mathrm{C}_{780}$ are the non-equilibrium eutectic points of $\mathrm{Al}-\mathrm{Si}$ alloy modified at $700{ }^{\circ} \mathrm{C}, 740{ }^{\circ} \mathrm{C}$ and $780{ }^{\circ} \mathrm{C}$, respectively. With the increase of modification temperature, the cooling rate of the alloy liquid became more rapid, and the undercooling degree of the alloy increased. Because Al-5Ti has little direct modification effect on hypereutectic Al-Si alloy, it has no influence on

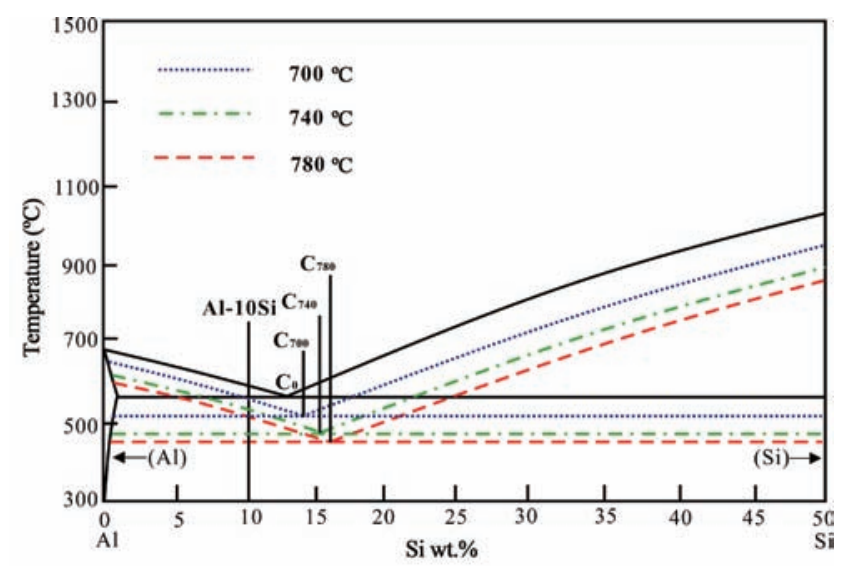

Fig. 4: Schematic of eutectic point variation of AI-Si alloy modified with $0.5 \mathrm{wt} . \% \mathrm{Al}-5 \mathrm{Ti}$

the undercooling degree of hypereutectic Al-Si alloy. Al5Ti has great modification effect on hypoeutectic Al-Si alloy, resulting in an obvious decrease of the undercooling degree of hypoeutectic Al-Si alloy. The synergetic effect of Al-5Ti modification and the temperature makes the non-equilibrium eutectic point of Al-Si alloy move to the right. With the increase of temperature, the moving distance of the non-equilibrium eutectic point to the right increased. According to Lever's law, the area fraction of primary $\alpha-\mathrm{Al}$ phase in modified Al-10Si alloy would increase.

\subsection{Mechanical properties of modified Al-10Si alloy}

Table 3 shows the ultimate tensile strength and elongation of unmodified Al-10Si alloy and the alloy modified with $0.5 \mathrm{wt} . \%$ Al-5Ti at $740{ }^{\circ} \mathrm{C}$. As shown in Table 3, the ultimate tensile strength and elongation of unmodified Al-10Si alloy are 176 $\mathrm{MPa}$ and 5.1\%, respectively. After modification with $0.5 \mathrm{wt} . \%$ Al-5Ti, the tensile properties of the alloy were obviously improved to $192 \mathrm{MPa}$ and $7.6 \%$, respectively.

The improvement of mechanical properties of the modified Al-10Si alloy is closely related to microstructure. Compared with unmodified Al-10Si alloy, the area fraction of the $\alpha$-Al phase increased from $41.4 \%$ to $52.8 \%$ after being modified with $0.5 \mathrm{wt} . \% \mathrm{Al}-5 \mathrm{Ti}$, resulting in a significant increase of elongation. In addition, the ultimate tensile strength of the Al-10Si alloy also increased due to the refinement of the $\alpha$-Al phase. The 
Table 3: Mechanical properties of Al-10Si alloy before and after modification with $0.5 \mathrm{wt} . \% \mathrm{Al}-5 \mathrm{Ti}$

\begin{tabular}{ccccc}
$\begin{array}{c}\text { Temperature } \\
\left({ }^{\circ} \mathrm{C}\right)\end{array}$ & \multicolumn{2}{c}{ Ultimate tensile strength $(\mathrm{MPa})$} & \multicolumn{2}{c}{ Elongation $(\%)$} \\
\hline 740 & Unmodified alloy & Modified alloy & Unmodified alloy & Modified alloy \\
\hline & $176 \pm 6$ & $192 \pm 8$ & $5.1 \pm 0.5$ & $7.6 \pm 0.2$ \\
\hline
\end{tabular}

refinement of the $\alpha-\mathrm{Al}$ indicates that the area of phase interface or grain boundaries increases, which could hinder the slip of dislocations and prevent the stress concentration.

Figure 5 shows the fracture morphology of the tensile samples of unmodified Al-10Si alloy and the alloy modified with $0.5 \mathrm{wt} . \%$ Al-5Ti at $740{ }^{\circ} \mathrm{C}$. As can be seen from Fig. 5(a), large cleavage

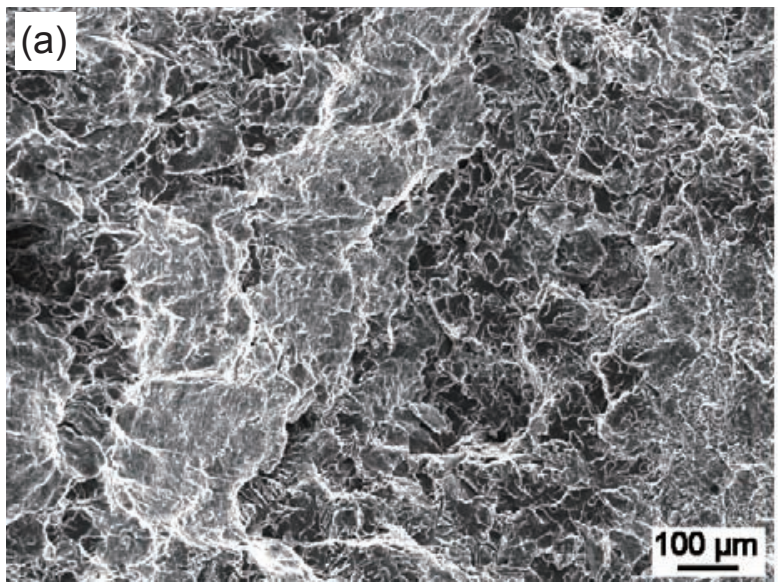

Fig. 5: Fracture morphology of tensile samples of Al-10S:

\section{Conclusions}

(1) The area fraction of the $\alpha$-Al phase in Al-10Si alloy increases first and then decreases with the increase of added amounts of Al-5Ti at $740{ }^{\circ} \mathrm{C}$. When the added amount of Al$5 \mathrm{Ti}$ is $0.5 \mathrm{wt} . \%$, the area fraction of $\alpha-\mathrm{Al}$ phase reaches the maximum.

(2) The $\alpha$-Al dendrites are obviously refined and the area fraction of $\alpha-\mathrm{Al}$ phase obviously increases when the modification temperature increases from 700 to $740{ }^{\circ} \mathrm{C}$ with addition of $0.5 \mathrm{wt} . \% \mathrm{Al}-5 \mathrm{Ti}$. From the point of view of the area fraction of $\alpha-\mathrm{Al}$ phase, the most suitable modification temperature is $740{ }^{\circ} \mathrm{C}$.

(3) Compared with unmodified Al-10Si alloy, the ultimate tensile strength and elongation of Al-10Si alloy modified with 0.5 wt. $\%$ Al- $5 \mathrm{Ti}$ at $740{ }^{\circ} \mathrm{C}$ are increased by $9 \%$ and $49 \%$, respectively. The fracture surface of the modified alloy exhibits a predominantly ductile fracture.

\section{References}

[1] Wang K, Jiang H Y, Wang Q D, et al. Nanoparticle-induced nucleation of eutectic silicon in hypoeutectic Al-Si alloy. Mater. Charact., 2016, 117: 41-46.

[2] Meenia S, Khan F, Babu S, et al. Particle refinement and finegrain formation leading to enhanced mechanical behaviour in a hypo-eutectic Al-Si alloy subjected to multi-pass friction stir platforms existed on the fractured surface of unmodified Al10Si alloy. After modification with 0.5wt.\% Al-5Ti, the size of cleavage platform in fracture surface of Al-10Si alloy decreased obviously, and the number of dimples and tear edges increased, as shown in Fig. 5(b). The fracture surface of the modified alloy exhibits a predominantly ductile fracture.

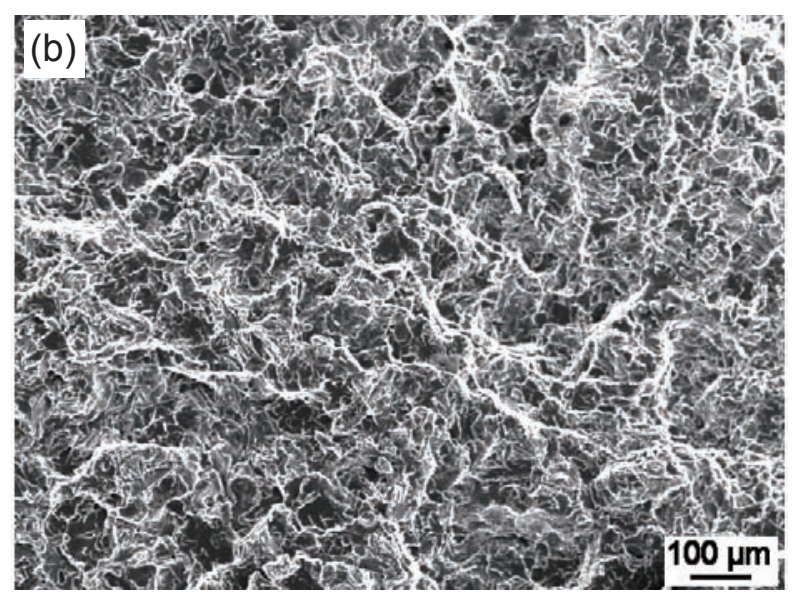

(a) unmodified; (b) modified with $0.5 \mathrm{wt} . \%$ Al-5Ti at $740{ }^{\circ} \mathrm{C}$

processing. Mater. Charact., 2016, 113: 134-143.

[3] Immanuel R J, Panigrahi S K. Influence of cryorolling on microstructure and mechanical properties of a cast hypoeutectic Al-Si alloy. Mater. Sci. Eng. A, 2015, 640: 424-435.

[4] Mueller M G, Fornabaio M, Žagar G, et al. Microscopic strength of silicon particles in an aluminium-silicon alloy. Acta Mater., 2016, 105: 165-175.

[5] Aguilera-Luna I, Castro-Román M J, Escobedo-Bocardo J C, et al. Effect of cooling rate and $\mathrm{Mg}$ content on the Al-Si eutectic for Al-Si-Cu-Mg alloys. Mater. Charact., 2014, 95(3): 211-218.

[6] Joseph S, Kumar S. Role of Si modification on the compressive flow behavior of Al-Si based alloy. Mater. Charact., 2015, 110: 272-281.

[7] Xu C, Xiao W, Hanada S, et al. The effect of scandium addition on microstructure and mechanical properties of Al-Si-Mg alloy: A multi-refinement modifier. Mater. Charact., 2015, 110: 160169.

[8] Jung J G, Lee S H, Lee J M, et al. Improved mechanical properties of near-eutectic Al-Si piston alloy through ultrasonic melt treatment. Mater. Sci. Eng. A, 2016, 669: 187-195.

[9] Jung J G, Lee S H, Cho Y H, et al. Effect of transition elements on the microstructure and tensile properties of Al-12Si alloy cast under ultrasonic melt treatment. J. Alloys Compd., 2017, 712.

[10] Kuchariková L, Tillová E, Chalupová M. The Si Particles Morphology in Hypoeutectic Al-Si Casts. Mater. Today Proceedings., 2016, 3(4): 1031-1036.

[11] Lei W, Liu X, Wang W, et al. On the influences of Li on the microstructure and properties of hypoeutectic Al-7Si alloy. J. Alloys Compd., 2017, 729.

[12] Haro-Rodríguez S, Goytia-Reyes R E, Dwivedi D K, et al. On influence of $\mathrm{Ti}$ and $\mathrm{Sr}$ on microstructure, mechanical properties 
and quality index of cast eutectic Al-Si-Mg alloy. Mater. Des., 2011, 32(4): 1865-1871.

[13] Wang B, Xue S, Wang J, et al. Effect of combinative addition of mischmetal and titanium on the microstructure and mechanical properties of hypoeutectic Al-Si alloys used for brazing and/or welding consumables. J. Rare Earth, 2017, 35(2): 193-202.

[14] Wang T, Fu H, Chen Z, et al. A novel fading-resistant Al-3Ti-3B grain refiner for Al-Si alloys. J. Alloys Compd., 2012, 511(1): 4549.

[15] Chen Z, Kang H, Fan G, et al. Grain refinement of hypoeutectic Al-Si alloys with B. Acta Mater., 2016, 120: 168-178.

[16] Toptan F, Kerti I, Daglilar S, et al. Production of Al-Ti-C Grain Refiners with the Addition of Elemental Carbon and K2TiF6. Light Metals, 2011, 49: 821-825.

[17] Ma T F, Chen Z Y, Nie Z R, et al. Microstructure of Al-Ti-B-Er refiner and its grain refining performance. J. Rare Earth, 2013, 31(6): 622-627.

[18] Gröbner J, Mirković D, Schmid-Fetzer R. Thermodynamic aspects of grain refinement of $\mathrm{Al}-\mathrm{Si}$ alloys using $\mathrm{Ti}$ and $\mathrm{B}$. Mater. Sci. Eng. A, 2005, 395(1-2): 10-21.

[19] Li J G, Zhang B Q, Wang L, et al. Combined effect and its mechanism of Al-3wt.\%Ti-4wt.\%B and Al-10wt.\%Sr master alloy on microstructures of Al-Si-Cu alloy. Mater. Sci. Eng. A, 2002, 328: 169-176.

[20] Dong X, Zhang Y, Ji S. Enhancement of mechanical properties in high silicon gravity cast AISi9Mg alloy refined by AI3Ti3B master alloy. Mater. Sci. Eng. A, 2017, 700: 291-300.

[21] Alamdari, Houshang D, Dube, et al. Behavior of Boron in Molten Aluminum and its Grain Refinement Mechanism. Metal. Mater. Trans. A, 2013, 44(1): 388-394.

[22] Xu C, Xiao W L, Zhao W T, et al. Microstructure and formation mechanism of grain-refining particles in Al-Ti-C-RE grain refiners. J. Rare Earth., 2015, 33(5): 553-560.

[23] Wang S, Fu M, Lu X W, et al. Microstructure and mechanical properties of Al-Si eutectic alloy modified with Al-3P master alloy. J. Mater. Process Tech., 2018, 255: 105-109.

[24] Wang S, Liu Y, Peng H P, et al. Microstructure and Mechanical Properties of Al-12.6Si Eutectic Alloy Modified with Al-5Ti Master Alloy. Adv. Eng. Mater., 2017, 255: 1-5.

[25] Wang Z J, Si N C. Synthesis and Refinement Performance of the Novel Al-Ti-B-RE Master Alloy Grain Refiner. Rare Metal Mat. Eng., 2015, 44(12): 2970-2975. 